\title{
PERILAKU PENCARIAN INFORMASI MAHASISWA UNIVERSITAS ISLAM INDONESIA
}

\author{
Arif Cahyo Bachtiar \\ Universitas Islam Indonesia \\ email: arifcahyo@uii.ac.id
}

\begin{abstract}
Abstrak:
Studi ini bertujuan untuk mengetahui bagaimana perilaku pencarian informasi mahasiswa di Universitas Islam Indonesia (UII).Metode yang digunakan ialah deskriptif dengan pendekatan kuantitatif. Teori yang digunakan untuk membangun indikator pada penelitian ini ialah teori dari David Ellis yang berisi karakteristik perilaku seseorang sebelum,saat, dan setelah pencarian informasi. Subjek penelitian ialah mahasiswa UII sebanyak 100 mahasiswa yang merupakan sampel dari seluruh mahasiswa aktif di UII. Hasil yang akan dicapai dalam penelitian ini ialah pola atau karakteristik perilaku mahasiswa UII dalam pencarian informasi. Hasil dari penelitian ini ialah Perilaku pencarian informasi mahasiswa Universitas Islam Indonesia sebelum proses pencarian informasi ialah positif. Hal ini dibuktikan dengan skor rata - rata yang di dapat pada tahap ini yaitu 2,95. Perilaku pencarian informasi mahasiswa Universitas Islam Indonesia saat proses pencarian informasi ialah positif. Hal ini dibuktikan dengan skor rata - rata yang di dapat pada tahap ini yaitu 2,65. Perilaku pencarian informasi mahasiswa Universitas Islam Indonesia setelah proses pencarian informasi juga positif. Hal ini ditunjukkan dengan skor rata - rata yang di dapat pada tahap ini yaitu 3,08. Secara keseluruhan, perilaku pencarian informasi mahasiswa Universitas Islam Indonesia menunjukkan ke arah yang positif. Ini ditunjukkan dengan skor rata-rata keseluruhan dari proses sebelum, saat, dan setelah pencarian informasi adalah 2,89. skor ini masuk pada interval 2,52-3,27.
\end{abstract}

Kata Kunci: Perilaku Pencarian Informasi, Karakteristik Pencarian Informasi, Mahasiswa Universitas Islam Indonesia

\begin{abstract}
:
This study aims to determine the information seeking behavior of students at the Islamic University of Indonesia. The method used is descriptive with a quantitative approach. The theory used to build indicators in this study is David Ellis' theory which contains the characteristics of a person's behavior before, during and after information search. The research subjects were 100 UII students who were a sample of all active students at UII. The results to be achieved in this study are the behavior patterns or characteristics of UII students in seeking information. The result of this research is that the information seeking behavior of Indonesian Islamic University students before the information search process is positive. This is evidenced by the average score obtained at this stage is 2.95. The information seeking behavior of Indonesian Islamic University students during the information search process was positive. This is evidenced by the average score obtained at this stage is 2.65. The information seeking behavior of Indonesian Islamic University students after the information seeking process was also positive. This is indicated by the average score obtained at this stage is 3.08. Overall, the information seeking behavior of Indonesian Islamic University students shows a positive direction. This is indicated by the overall average score of the process before, during, and after information seeking is 2.89. this score is included in the interval 2.52-3.27.
\end{abstract}

Keywords: Information Seeking Behavior, Characteristics of Information Seeking, Indonesian Islamic University Students

\section{PENDAHULUAN}

Saat ini informasi merupakan sebuah enti-

tas yang sangat berharga bagi manusia.Informasi

dibutuhkan untuk mendukung pekerjaan yang dilakukan manusia. Wawasan dan pengetahuan manusia juga akan berkembang dengan adanya informasi ini. Pentingnya sebuah informasi ini 
menjadikan manusia harus berhati-hati dalam mencari dan menggunakannya.Akses kepada informasi manapun terbuka luas di genggaman kita dengan adanya teknologi-teknologi yang terus berkembang.Informasi dibutuhkan oleh semua lapisan masyarakat seperti pada bidang politik, pendidikan, dan sebagainya.Kebutuhan informasi tiap-tiap individu sangat beragam. Informasi tersebut bias bersifat umum, atau khusus yang berkaitan dengan pekerjaan atau sekedar hobinya.

Dengan beragamnya kebutuhan informasi setiap orang, maka cara orang dalam mendapatkan informasi tersebut juga beragam. Hal ini juga bergantung pada tujuan seseorang mencari informasi tersebut. Kebutuhan informasi yang berbeda akan menimbulkan proses pencarian informasi yang berbeda pula. Informasi tersebut juga akan digunakan untuk tujuan yang berbedabeda. Hal ini memunculkan sebuah perilaku pencarian informasi.Perilaku pencarian informasi dapat menjadi sebuah pondasi awal bagaimana informasi yang dicari, diolah, dan disebarkan kembali oleh seorang sivitas akademik tersebut. Dalam proses akademik, informasi yang dihasilkan ialah oleh para sivitas ialah informasi yang ilmiah, hasil dari sebuah kajian, dan tentu dapat dipertanggungjawabakan dalam sebuah terbitan ilmiah. Dalam siklusnya, terbitan ilmiah ini dimulai dari pencarian informasi untuk menyusun sebuah tulisan atau penelitian, kemudian informasi tersebut diolah dalam penelitiannya sehingga menghasilkan sebuah karya ilmiah baru. Karya ilmiah tersebut akan kembali dicari oleh orang lain untuk kemudian dijadikan sebagai informasi kembali dalam sebuah karya ilmiah. Demikianlah alur informasi yang terjadi di kalangan akademik. Maka, perilaku pencarian informasi sebagai langkah awal dalam proses pendistribusian informasi ini sangat penting untuk diperhatikan dan dikaji. Karena dari perilaku pencarian informasi tersebut akan berpengaruh pada karya-karya ilmiah yang akan dihasilkan di masa yang akan datang.

Universitas Islam Indonesia (UII) sebagai salah satu institusi akademik tertua di Indonesia merupakan sebuah lembaga pendidikan yang memiliki ribuan civitas akademik dengan berbagai latar belakang dan bidang akademik yang dijalaninya. Sebagai sebuah lembaga akademik, tentu saja terdapat siklus informasi yang berjalan pada proses akademiknya. Informasi dibutuhkan para sivitas akademiknya untuk membuat sebuah karya ilmiah. Informasi yang ditemukan tersebut kemudian akan diolah dalam berbagai kajian atau penelitian yang berjalan di kampus ini. Pada akhirnya hasil dari kajian tersebut akan menjadi sebuah informasi baru yang beredar secara luas dan akan dibutuhkan oleh sivitas akdemik lainnya sebagai sebuah informasi baru. Dari beberapa kalangan sivitas akademik yang dimiliki UII, mahasiswa merupakan kalangan sivitas akademik yang terbanyak jumlahnya.Tercatat pada laman Forlap DIKTI, jumlah mahasiswa aktif UII sebanyak 28.611.Artinya, kalangan mahasiswalah yang paling banyak membutuhkan informasi, serta menghasilkan informasi baru melalui tugas akhir ataupun pene- 
litiannya.Hal ini membuat peneliti tertarik untuk mengetahui bagaimana karakteristik atau perilaku pencarian informasi kalangan mahasiswa di UIIPerilaku pencarian informasi penting untuk diketahui karena dapat memberikan pandangan holistik tentang perilaku informasi. Karena hubungan antara kepribadian dan perilaku telah dipelajari sebagai sarana untuk memprediksi kecenderungan individu untuk memproses informasi ${ }^{1}$.

Hasil pengamatan yang dilakukan sebelum penelitian berlangsung menunjukkan bahwa masih banyak mahasiswa yang belum menggunakan cara-cara yang efektif dalam pencarian literatur atau informasi untuk kebutuhan akademiknya. Hal ini berkaitan pula dengan perilaku pencarian informasi dari mahasiswa-mahasiswa tersebut.Oleh karena itu, penulis tertarik untuk melakukan penelitian tentang bagaimana perilaku pencarian informasi mahasiswa Universitas Islam Indonesia. Tujuan dari penelitian ini ialah untuk mengetahui bagaimana gambaran perilaku sebelum, saat, serta setelah pencarian informasi oleh mahasiswa Universitas Islam Indonesia. Selain itu penelitian ini juga bertujuan untuk memberikan gambaran kepada institusi terkait pola pencarian informasi mahasiswa agar dapat dijadikan sebagai dasar pembuatan program kerja bagi universitas maupun perpustakaan.

\section{TINJAUAN PUSTAKA}

\footnotetext{
${ }^{1}$ Al-Samarraie, H., Eldenfria, A., \& Dwoud, H. (2017). The impact of personalitu trains on user information-seeking behavior. Information Processing and Management, 53(1), 237-247. https://doi.org/10.1016/j.ipm.2016.08.004
}

Informasi ialah data yang disajikan dalam bentuk yang mudah dipahami dimana makna telah dikaitkan dalam konteks penggunanya.Dalam arti yang lebih dinamis, informasi merupakan pesan yang disampaikan dengan menggunakan media komunikasi atau ekspresi.Pesan dapat bersifat informatif atau tidak tergantung pada persepsi subjektif seseorang yang menerimanya. Dalam Bahasa yang lebih konkrit, informasi ialah semua fakta, kesimpulan, ide, dan karya kreatif dari kecerdasan dan imajinasi manusia yang telah dikomunikasikan secara formal atau informal dalam bentuk apapun ${ }^{2}$

Kebutuhan informasi setiap individu pasti berbeda-beda. Dalam kasus ini, kebutuhan informasi para mahasiswa diploma, sarjana, maupun pascasarjana pasti akan berbeda. Faktorfaktor yang mempengaruhi kebutuhan informasi ialah kebutuhan kognitif, kebutuhan afektif kebutuhan integrasi personal kebutuhan integrasi sosial kebutuhan berkhayal ${ }^{3}$.

David Ellis dalam buku yang berjudul Progres and Problems in Information Retrival mengemukakan proses pencarian informasi ke dalam 8 karakteristik yang dikelompokkan menjadi 3 kelompok yaitu ${ }^{4}$ :

a. Sebelum pencarian informasi

\footnotetext{
${ }^{2}$ Reitz, J.M. (n.d). Online Dictionary for Library and Information Science. January 13, 2019, from https://www.abc-clio.com/ODLIS/odlis_i.aspx

${ }^{3}$ Ningrum, D. R., Saleh, C., \& Widia Permana. (2015). PENGARUH KEBUTUHAN INFORMASI PEMUSTAKA TERHADAP PENGEMBANGAN KOLEKSI BUKU TERCETAK PADA PERPUSTAKAAN UNIVERSITAS BRAWIJAYA (Studi pada Mahasiswa S1 Jurusan Administrasi Publik Universitas Brawijaya).Jurnal Adminsitrasi Publik (JAP), 3(5).

${ }^{4}$ Wiranata, A., Prijana, \& Rodiah, S. (2012). Perilaku Users dalam Pencarian Data dan Informasi melalui New Media.Students EJournal, 1(1).
} 
1) Starting, adalah kegiatan awal pencarian informasi seperti menentukan referensi yang bisa dijadikan titik awal dalam pencarian informasi. Dalam penelitian ini dijabarkan menjadi beberapa indikator yaitu: penentuan topik; bertanya sebelum pencarian informasi; membaca literatur lain; menentukan kata kunci serta media pencarian.

2) Chaining, adalah kegiatan menelusuri sitasi atau sumber-sumber yang diidentifikasi selama kegiatan starting. Dalam penelitian ini dijabarkan menjadi indikator penentuan sumber informasi original.

b. Saat pencarian informasi

1) Browsing, adalah kegiatan mencari informasi di berbagai tempat yang dianggap memiliki potensi akan keberadaan informasi yang dicari. Dalam penelitian ini dijabarkan menjadi beberapa indikator yaitu: mendatangi rak; menggunakan katalog; melihat daftar isi jurnal; mengunakan internet.

2) Differentiating, merupakan kegiatan memilih informasi yang didapat dengan menggunakan pembacaan dari ciri-ciri sumber informasi misalnya pengarang, cakupan, tingkat detail, dan kualitas informasi. Dalam penelitian ini dijabarkan menjadi indikator pemilihan sumber informasi.

3) Monitoring, adalah kegiatan mengikuti perkembangan dari sumber-sumber tertentu sehingga mendapatkan informasi yang update misalnya dengan jurnal, koran, konferensi, majalah, dan sebagainya. Dalam penelitian ini dijabarkan menjadi indikator pemantauan terhadap informasi terbaru

c. Perilaku setelah pencarian informasi

1) Extracting, ialah kegiatan yang berhubungan dengan melanjutkan pencarian dengan menggali lebih dalam dari sumber informasi tertentu dan selektif dalam menentukan bahan yang relevan dari sumbersumber yang ditemukan. Dalam penelitian ini dijabarkan menjadi beberapa indikator yaitu: pencarian informasi lebih lanjut; pemilihan informasi yang relevan.

2) Verifying, tahap ini merupakan tahap dimana pencari informasi mengece kembali apakah informasi yang didapatkannya sudah tepat dan sesuai dengan kebutuhannya. Selain itu pada tahap ini juga pencari informasi akan mengecek keakuratan dari informasi yang ditemukannya Dalam penelitian ini dijabarkan menjadi indikator pengecekan informasi yang telah ditemukan.

3) Ending, adalah tahap akhir dari pencarian informasi dan menggunakan informasi yang diperoleh. Dalam penelitian ini dijabarkan beberapa indikator penggunaan informasi yang telah diperoleh.

Karakteristik yang dikemukakan oleh Ellis tersebut akan menjadi indikator dalam penelitian ini. Dari karakteristik tersebut dibangun angket berupa pertanyaan-pertanyaan yang berkaitan 
dengan karakteristik perilaku pencarian informasi mahasiswa Universitas Islam Indonesia.

\section{METODE PENELITIAN}

Penelitian ini menggunakan pendekatan kuantitatif dengan metode deskriptif.Pendekatan penelitian kuantitatif menekankan fenomenafenomena objektif dan dikaji secara kuantitatif.Penelitian ini mendeskripsikan secara kuantitatif bagaimana perilaku mahasiswa UII dalam pencarian informasi. Penelitian dilakukan di Direktorat Perpustakaan UII Yogyakarta. Penelitian dilakukan pada bulan Maret - Juni 2020.Subjek dalam penelitian ini ialah mahasiswa UII.Sedangkan objek dalam penelitian ini ialah perilaku pencarian informasi.Populasi dalam penelitian ini ialah mahasiswa aktif Universitas Islam Indonesia yang UII yang berjumlah 28.611 orang (data forlap Dikti).

Besaran sampel dalam penelitian ini adalah 100 orang mahasiswa UII, ditentukan dengan rumus Slovin menggunakan besaran nilai kritis sebesar 10\%.Sampel dipilih berdasarkan accidental sampling yang merupakan teknik pemilihan sampel dari siapa saja yang kebetulan dijumpai oleh peneliti.Sampel yang dipilih ialah setiap mahasiswa yang berkunjung ke Direktorat Perpustakaan UII.

\section{HASIL DAN PEMBAHASAN}

\section{Perilaku Pencarian Informasi Mahasiswa Universitas Islam Indonesia Sebelum Men- cari Informasi}

Tabel 1. Rekap data perilaku pencarian informasi mahasiswa Universitas Islam Indonesia sebelum pencarian informasi

\begin{tabular}{|l|l|l|l|}
\hline No & Pernyataan & Skor & Jawaban \\
\hline
\end{tabular}

\begin{tabular}{|c|l|c|c|}
\hline 1 & $\begin{array}{l}\text { Penentuan topik in- } \\
\text { formasi }\end{array}$ & 3,62 & $\begin{array}{c}\text { Sangat } \\
\text { Positif }\end{array}$ \\
\hline 2 & $\begin{array}{l}\text { Bertanya pada dosen } \\
\text { mengenai informasi } \\
\text { yang dibutuhkan }\end{array}$ & 2,47 & Negatif \\
\hline 3 & $\begin{array}{l}\text { Bertanya pada pusta- } \\
\text { kawan mengenai in- } \\
\text { formasi yang dibutuh- } \\
\text { kan }\end{array}$ & 2,60 & Positif \\
\hline 4 & $\begin{array}{l}\text { Bertanya kepada te- } \\
\text { man mengenai infor- } \\
\text { masi yang dibutuhkan }\end{array}$ & 2,91 & Positif \\
\hline 5 & $\begin{array}{l}\text { Membaca literatur } \\
\text { seperti skripsi, tesis, } \\
\text { dan disertasi sebagai } \\
\text { bahan referensi }\end{array}$ & 3,02 & Positif \\
\hline 6 & $\begin{array}{l}\text { Menyiapkan kata kun- } \\
\text { ci mengenai informasi } \\
\text { yang ingin diperoleh }\end{array}$ & 3,42 & $\begin{array}{l}\text { Sangat } \\
\text { Positif }\end{array}$ \\
\hline 7 & $\begin{array}{l}\text { Menentukan serta } \\
\text { membuat daftar in- } \\
\text { formasi yang ingin } \\
\text { dicari }\end{array}$ & 3,32 & Sangat \\
\hline 8 & $\begin{array}{l}\text { Menentukan media } \\
\text { yang akan digunakan } \\
\text { untuk pencarian in- } \\
\text { formasi }\end{array}$ & 3,16 & Positif \\
\hline 9 & $\begin{array}{l}\text { Menggunakan infor- } \\
\text { masi yang tidak origi- } \\
\text { nal }\end{array}$ & 2,19 & Negatif \\
\hline 10 & $\begin{array}{l}\text { Mencari sumber in- } \\
\text { formasi original }\end{array}$ & 2,87 & Positif \\
\hline Total Skor & 29,58 \\
\hline Skor Rata - rata & 2,95 \\
\hline
\end{tabular}

Jumlah skor total pada rekapitulasi data perilaku pencarian informasi mahasiswa Universitas Islam Indonesia sebelum pencarian informasi adalah 29,58 dengan rata- rata 2,95. Skor tersebut masuk pada skala interval 2,52 - 3,27 yang artinya perilaku mahasiswa Universitas Islam Indonesia sebelum pencarian informasi adalah positif.

Pernyataan terkait penentuan topik sebelum melakukan pencarian informasi mendapat skor 
yang paling besar dengan skor sebesar 3,62 yang berada pada skala interval 3,28 - 4,03 yang berarti sangat positif. Sedangkan skor terendah terkait perilaku pencarian mahasiswa Universitas Islam Indonesia sebelum pencarian informasi berada pada pernyataan terkait menggunakan informasi yang tidak original dengan skor 2,19 yang berada pada skala interval 1,76-2,51 yang berarti negatif

\section{Perilaku pencarian informasi mahasiswa Universitas Islam Indonesia saat pencarian informasi}

Tabel 2. Rekap data perilaku pencarian informasi mahasiswa Universitas Islam Indonesia saat pencarian informasi

\begin{tabular}{|c|l|c|c|}
\hline No & \multicolumn{1}{|c|}{ Pernyataan } & Skor & Jawaban \\
\hline 1 & $\begin{array}{l}\text { Langsung mendatan- } \\
\text { girak untuk mencari } \\
\text { buku }\end{array}$ & 2,92 & Positif \\
\hline 2 & $\begin{array}{l}\text { Menggunakan katalog } \\
\text { dengan pencarian spe- } \\
\text { sifik }\end{array}$ & 2,28 & Negatif \\
\hline 3 & $\begin{array}{l}\text { Menggunakan katalog } \\
\text { dengan pencarian se- } \\
\text { derhana }\end{array}$ & 3,04 & Positif \\
\hline $\mathbf{4}$ & $\begin{array}{l}\text { Menelusur daftarisi } \\
\text { jurnal }\end{array}$ & 1,54 & $\begin{array}{l}\text { Sangat } \\
\text { Negatif }\end{array}$ \\
\hline 5 & $\begin{array}{l}\text { Menggunakan internet } \\
\text { ketika mencari informa- } \\
\text { si }\end{array}$ & 3,28 & $\begin{array}{l}\text { Sangat } \\
\text { Positif }\end{array}$ \\
\hline 6 & $\begin{array}{l}\text { Mencari informasi di } \\
\text { internet menggunkan } \\
\text { boolean logic operator } \\
\text { (AND, OR, NOT) }\end{array}$ & 1,87 & Negatif \\
\hline $\mathbf{7}$ & $\begin{array}{l}\text { Memilih informasi dari } \\
\text { sumber yang dapat } \\
\text { dipertanggung jawab- } \\
\text { kan }\end{array}$ & 3,37 & $\begin{array}{l}\text { Sangat } \\
\text { Positif }\end{array}$ \\
\hline $\mathbf{8}$ & $\begin{array}{l}\text { Memantau informasi } \\
\text { terbaru dari berbagai } \\
\text { sumber informasi }\end{array}$ & 2,88 & Poitif \\
\hline Total Skor & 2,65 \\
\hline Skor Rata - rata & \multicolumn{2}{|c|}{} \\
\hline
\end{tabular}

Jumlah skor total pada rekapitulasi data perilaku pencarian informasi mahasiswa Universitas Islam Indonesia saat pencarian informasi adalah 21,18 dengan rata- rata 2,65. Skor tersebut masuk pada skala interval 2,52-3,27 yang artinya perilaku mahasiswa Universitas Islam Indonesia pada saat pencarian infoormasi adalah positif.

Pernyataan memilih informasi dari sumber yang dapat dipertanggung jawabkan mendapat skor yang paling besar degnan skor sebesar 3,37 berada pada skala interval 3,28 - 4,03 yang berarti sangat positif. Sedangkan skor terendah terkait perilaku pencarian mahasiswa Universitas Islam Indonesia pada saat pencarian informasi berada pada pernyataan terkait menelusur daftarisi jurnal dengan skor 1,87 berada pada skala interval 1,76-2,51 yang berarti negatif.

\section{Perilaku Pencarian Informasi Mahasiswa Universitas Islam Indonesia SetelahMenca- ri Informasi}

Tabel 3. Rekap data perilaku pencarian informasi mahasiswa Universitas Islam Indonesia setelah pencarian informasi

\begin{tabular}{|c|l|c|c|}
\hline No & \multicolumn{1}{|c|}{ Pernyataan } & Skor & Jawaban \\
\hline 1 & $\begin{array}{l}\text { Melakukan pencarian } \\
\text { lebih lanjut untuk men- } \\
\text { dapatkan informasi yang } \\
\text { lebih mendalam }\end{array}$ & 3,18 & Positif \\
\hline 2 & $\begin{array}{l}\text { Memilih informasi yang } \\
\text { relevan dengan kebutu- } \\
\text { han }\end{array}$ & 3,86 & $\begin{array}{l}\text { Sangat } \\
\text { Positif }\end{array}$ \\
\hline 3 & $\begin{array}{l}\text { Melakukan pembuktian } \\
\text { terhadap sumber infor- } \\
\text { masi yang dipilih dengan } \\
\text { cara membandingkan } \\
\text { dengan sumber informasi } \\
\text { lainnya }\end{array}$ & 2,72 & Positif \\
\hline
\end{tabular}




\begin{tabular}{|c|l|c|c|}
\hline 4 & $\begin{array}{l}\text { Mengecek ulang informa- } \\
\text { si yang ditemukan }\end{array}$ & 2,88 & Positif \\
\hline 5 & $\begin{array}{l}\text { Menentukan informasi } \\
\text { yang diperoleh untuk } \\
\text { digunakan }\end{array}$ & 2,76 & Positif \\
\hline Total Skor & $\mathbf{1 5 , 4}$ \\
\hline Skor Rata - rata & $\mathbf{3 , 0 8}$ \\
\hline
\end{tabular}

Jumlah skor total pada rekapitulasi data perilaku pencarian informasi mahasiswa Universitas Islam Indonesia saat pencarian informasi adalah 15,4 dengan rata- rata 3,08 . Skor tersebut masuk pada skala interval 2,52-3,27 yang artinya perilaku mahasiswa Universitas Islam Indonesia setelah pencarian informasi adalah positif.

Pernyataan terkait memilih informasi yang relevan dengan kebutuhan dengan skor sebesar 3,86 yang berada pada skala interval 3,28 4,03 yang berarti sangat positif. Sedangkan skor terendah terkait perilaku pencarian mahasiswa Universitas Islam Indonesia setelah pencarian informasi berada pada pernyataan terkait melakukan pembuktian terhadap sumber informasi yang dipilih dengan cara membandingkan dengan sumber informasi lainnya dengan skor 2,72. Meski demikian pernyataan tersebut bernilai positif karena masih berada pada interval 2,523,27 .

Mahasiswa Universitas Islam Indonesia dalam kaitannya dengan proses pencarian informasi, ternyata lebih banyak memilih untuk bertanya kepada temannya dibandingkan bertanya pada dosen atau pustakawan. Hal ini menunjukkan bahwa peran pustakawan masih kurang dimanfaatkan oleh mahasiswa. Dengan skor rata-rata 2,60, lebih dari $50 \%$ mahasiswa yang menjadi responden jarang bahkan tidak pernah bertanya pada pustakawan mengenai informasi yang dibutuhkan. Skor rata-rata yang lebih rendah ialah 2,47 pada pernyataan bertanya pada dosen mengenai informasi yang dibutuhkan. Penulis menyimpulkan bahwa para mahasiswa lebih nyaman untuk berdiskusi dengan temannya mengenai informasi yang dibutuhkan daripada dengan dosen maupun pustakawan.Dalam kasus ini fungsi pustakawan sebagai edukator yang melakukan pendidikan pemakai berupa bimbingan penelusuran informasi bagi pengguna masih kurang.

Dalam pemilihan bahan referensi, sebagian besar mahasiswa Universitas Islam Indonesia memilih untuk membaca literatur karya tugas akhir mahasiswa seperti skripsi, tesis, dan disertasi.Lebih dari $50 \%$ responden menyatakan selalu dan sering memanfaatkan literatur tugas akhir mahasiswa tersebut sebagai bahan referensinya.Hal ini didukung dengan adanya pengelolaan karya tugas akhir mahasiswa di Direktorat Perpustakaan UII yang sudah baik.Perpustakaan UII menyediakan literatur tugas akhir mahasiswa dalam format digital yang dapat diakses secara bebas oleh mahasiswa.Dengan demikian, mahasiswa diberikan kemudahan untuk mengakses literatur tersebut sebagai bahan referensi mereka.Namun, masih terdapat $6 \%$ mahasiswa yang

\footnotetext{
${ }^{5}$ Lestari, P. D., \& Jumino. (2017). PERAN PUSTAKAWAN DALAM PENCARIAN INFORMASI MAHASISWA DI UPT PERPUSTAKAAN UNIVERSITAS NGUDI WALUYO KECAMATAN UNGARAN KABUPATEN SEMARANG. Jurnal Ilmu Perpustakaan, 6(4). https://ejournal3.undip.ac.id/index.php/jip/article/view/23 211
} 
tidak pernah membaca literatur tugas akhir mahasiswa ini sebagai bahan referensinya. Hal ini menandakan perpustakaan UII harus lebih giat lagi dalam mempromosikan koleksi berupa karya tugas akhir mahasiswa, atau dengan cara memperbaiki infrastruktur teknologi yang digunakan dalam menyajikan karya tugas akhir bentuk digital tersebut. Saat ini perpustakaan UII menggunakan platform DSpace Digital Library untuk melayankan koleksi tugas akhir mahasiswa.

Mahasiswa Universitas Islam Indonesia sudah sangat paham pentingnya sebuah keyword atau kata kunci dalam pencarian informasi.Data menunjukkan bahwa tidak ada responden yang tidak pernah menyiapkan kata kunci terlebih dahulu sebelum melakukan pencarian informasi.Bahkan, lebih dari 50\% mahasiswa menyatakan bahwa mereka selalu menyiapkan kata kunci terlebih dahulu mengenai informasi yang ingin diperolehnya.Hal ini menandakan bahwa penyiapan kata kunci sebelum memulai penelusuran informasi bagi mahasiswa sudah sangat baik.Selain itu, mahasiswa Universitas Islam Indonesia lebih memilih menggunakan sumber informasi yang original daripada yang tidak.Hal ini ditunjukkan oleh skor rata-rata dari mahasiswa yang menggunakan informasi original lebih tinggi daripada menggunakan informasi yang tidak original.Dalam hal ini dapat dikatakan bahwa peran perpustakaan dalam menyediakan sumber-sumber literatur yang original dan dapat dipertanggung jawabkan sudah sangat baik.Sumber informasi yang disediakan perpus- takaan UII merupakan sumber yang original dan dapat dipertanggung jawabkan sumbernya.

Pada saat proses pencarian informasi khususnya di perpustakaan, lebih dari 50\% para mahasiswa menyatakan selalu dan sering langsung mendatangi rak untuk mencari buku. Ini berarti anjungan katalog yang telah disediakan di perpustakaan kurang termanfaatkan.Hal ini juga berkaitan dengan data sebelumnya yang menunjukkan sebagian besar mahasiswa lebih memilih untuk bertanya kepada temannya dalam hal pencarian informasi dari pada bertanya kepada pustakawan maupun dosen.Pustakawan juga dapat melatih mahasiswa menggunakan katalog dengan pencarian spesifik.Lebih dari $50 \%$ mahasiswa menyatakan bahwa mereka jarang dan bahkan tidak pernah menggunakan katalog dengan pencarian spesifik yang berfungsi untuk memfilter hasil pencarian.

Sumber informasi dalam bentuk digital yang dapat diakses secara online sangat diminati oleh mahasiswa.Hal ini ditunjukkan dengan data yang hampir 100\% mahasiswa menggunakan internet ketika mencari informasi.Sebagian besar sumber-sumber informasi yang tersedia dan dikelola oleh perpustakaan saat ini sudah dapat diakses secara online.

Pada tahap setelah proses pencarian informasi, sebagian besar mahasiswa telah melakukan pencarian lebih lanjut untuk mendapatkan informasi yang lebih mendalam. Lebih dari 50\% mahasiswa menyatakan bahwa mereka melakukan pencarian lebih lanjut. Ini berarti mahasiswa telah memiliki ketertarikan untuk menemukan 
atau mendapatkan informasi yang lebih detail dan spesifik. Hal ini juga berkaitan dengan kebutuhan mereka untuk memilih informasi yang relevan dengan kebutuhan.Tidak semua hasil pencarian yang ditemukan oleh mahasiswa merupakan informasi yang dibutuhkannya.

\section{KESIMPULAN DAN SARAN}

\section{Kesimpulan}

Berdasarkan hasil penelitian serta pembahasan yang dipaparkan, maka kesimpulan dalam penelitian ini ialah sebagai berikut:

a. Perilaku pencarian informasi mahasiswa Universitas Islam Indonesia sebelum proses pencarian informasi ialah positif. Hal ini dibuktikan dengan skor rata - rata yang di dapat pada tahap ini yaitu 2,95 dimana skor ini masuk pada interval 2,52-3,27.

b. Perilaku pencarian informasi mahasiswa Universitas Islam Indonesia saat proses pencarian informasi ialah positif. Hal ini dibuktikan dengan skor rata - rata yang di dapat pada tahap ini yaitu 2,65 dimana skor ini masuk pada interval 2,52-3,27.

c. Perilaku pencarian informasi mahasiswa Universitas Islam Indonesia setelah proses pencarian informasi juga positif. Hal ini ditunjukkan dengan skor rata - rata yang di dapat pada tahap ini yaitu 3,08 dimana skor ini masuk pada interval 2,52-3,27.

d. Secara keseluruhan, perilaku pencarian informasi mahasiswa Universitas Islam Indonesia menunjukkan ke arah yang positif. Ini ditunjukkan dengan skor rata-rata keseluruhan dari proses sebelum, saat, dan setelah penca- rian informasi adalah 2,89. skor ini masuk pada interval 2,52-3,27.

\section{Saran}

Berdasarkan pembahasan serta kesimpulan di atas, peneliti menyampaikan beberapa saran sebagai berikut:

a. Perpustakaan melalui pustakawannya harus lebih menjalankan fungsinya sebagai edukator juga pendamping dalam hal penelusuran informasi bagi mahasiswa khususnya di dalam perpustakaan.

b. Perpustakaan dapat membuat sebuah program atau kelas literasi informasi yang berisi materi-materi tentang teknik penelusuran informasi.

c. Kegiatan promosi tentang sumber-sumber informasi di perpustakaan dapat lebih ditingkatkan kembali, tidak hanya dengan program pengenalan perpustakaan kepada mahasiswa baru di awal tahun ajaran saja.

\section{Daftar Pustaka}

Al-Samarraie, H., Eldenfria, A., \& Dwoud, H. (2017). The impact of personalitu trains on user information-seeking behavior. Information Processing and Management, 53(1), 237-247. https://doi.org/10.1016/j.ipm.2016.08. $00 \quad 4$

Lestari, P. D., \& Jumino. (2017). PERAN PUSTAKAWAN DALAM PENCARIAN INFORMASI MAHASISWA DI UPT PER PUSTAKAAN UNIVERSITAS NGUDI WALUYO KECAMATAN UNGARAN KABUPATEN SEMARANG. Jurnal Ilmu Perpustakaan, 6(4). https://ejournal3.undip.ac.id/index.php/ ịp /article/view/23211 
Ningrum, D. R., Saleh, C., \& Widia Permana. (2015). PENGARUH KEBUTUHAN IN FORMASI PEMUSTAKA TERHADAP PENGEMBANGAN KOLEKSI BUKU TERCETAK PADA PERPUSTAKAAN UNIVERSITAS BRAWIJAYA (Studi pada Mahasiswa S1 Jurusan Administrasi Publik Universitas Brawijaya).Jurnal Adminsitrasi Publik (JAP), 3(5).

Reitz, J.M. (n.d). Online Dictionary for Library and Information Science. January 13, 2019, from https://www.abcclio.com/ODLIS/odlis_i.aspx

Wiranata, A., Prijana, \& Rodiah, S. (2012). Perilaku Users dalam Pencarian Data dan Informasi melalui New Media. Students E-Journal,1(1). 